\title{
Comparative Analysis of Heavy Metals And Proximate Composition of Capsicum annuum (Pepper) and Allium cepa L.(Onion)
}

\author{
Salisu A ${ }^{1 *}$, Adamu A. $\mathrm{U}^{2}$, Abdulmumin $\mathrm{Y}^{3}$, Muhammad I. $\mathrm{U}^{4}$ \\ ${ }^{\mathrm{T}}$ Department of Agriculture, College of Agriculture and Technology, Hussaini Adamu Federal Polytechnic Kazaure, \\ Jigawa State, Nigeria \\ ${ }^{2}$ Department of Polymer Technology, College of Science, Hussaini Adamu Federal Polytechnic Kazaure, Jigawa State, \\ Nigeria \\ ${ }^{3}$ Department of Biochemistry, Faculty of Sciences, Kano University of Science and Technology Wudil, Kano, Nigeria \\ ${ }^{4}$ Department of Medical Biochemistry, College of Medical Sciences, Yobe State University, Damaturu, Yobe, Nigeria
}

*Corresponding Author

Salisu A

\author{
Article History \\ Received: 03.03.2020 \\ Accepted: 15.03 .2020 \\ Published: 21.03.2020
}

\begin{abstract}
The increasing demand for food safety stimulated research regarding their nutritional content as well the risk associated with consumption of foodstuffs contaminated by heavy metals and/or toxins. This study was designed to determine heavy metal content and proximate composition of Capsicum annuum (Pepper) and Onions (Allium cepa L.) obtained from two farming communities of Kazaure Local Government, Jigawa State, Nigeria. The heavy metals were analyzed using Atomic Absorption Spectrometer (AAS), while the proximate compositions were carried out using standard methods of Association of Official Analytical Chemists (AOAC, 1980). The heavy metal levels determined were based on plants dry weight, the mean level of $\mathrm{Pb}, \mathrm{Cd}$ and $\mathrm{Mn}$ were not detected from the pepper obtained from Gada farming community, while $\mathrm{Zn}, \mathrm{Cu}$ and Fe were found to be $1.5 \pm 0.10,0.74 \pm 0.02$ and $4.21 \pm 0.33 \mathrm{mg} / \mathrm{kg}$ respectively. Onion obtained from Gada area showed no any detectable level of $\mathrm{Pb}$, however, $\mathrm{Cd}, \mathrm{Mn}, \mathrm{Zn}, \mathrm{Cu}$ and Fe were found to be $0.002 \pm 0.001,0.11 \pm 0.001,1.8 \pm 0.20,0.91 \pm 0.03$ and $3.85 \pm 0.36 \mathrm{mg} / \mathrm{kg}$ respectively. The soil sample of this area showed that the mean heavy metal level of $\mathrm{Pb}, \mathrm{Cd}, \mathrm{Mn}, \mathrm{Zn}, \mathrm{Cu}$ and $\mathrm{Fe}$ were found to be $0.20 \pm 0.002,0.16 \pm 0.02,231.1 \pm 7.00$, $47.4 \pm 4.11,32.2 \pm 5.00,200 \pm 8.00 \mathrm{mg} / \mathrm{kg}$ respectively. The proximate analysis of the two varieties of vegetables Capsicum annuum(Pepper)and Allium cepa L (Onion) from two farming areas revealed that the onion showed higher ash, moisture, carbohydrate, fibre, crude fat and protein content than that of pepper as well the Gada farming area has higher proximate content than Firji farming area. The ash, moisture, carbohydrate fibre, crude fat and protein content for onion obtained from Gada were $6.10 \pm 0.20,9.30 \pm 1.00,64.00 \pm 5.00,4.47 \pm 1.00,14.60 \pm 2.10$ and $13.70 \pm 0.01$ respectively. While for pepper were found to be $4.35 \pm 0.10,5.70 \pm 0.15,62.94 \pm 0.0,2.61 \pm 0.01,12.70 \pm 0.10$ and $11.70 \pm 0.13$ respectively. The ash, moisture, carbohydrate fibre, crude fat and protein content for onion obtained from Firji were 5.20 $\pm 0.20,8.20 \pm 1.00$, $60.00 \pm 5.00,3.89 \pm 1.00,11.50 \pm 2.10$ and $11.60 \pm 0.01$ respectively and that of pepper were $3.34 \pm 0.10,3.90 \pm 0.15$, $59.34 \pm 0.01,1.91 \pm 0.01,10.40 \pm 0.10$ and $9.80 \pm 0.13 \%$ respectively. Conclusively, the levels of metals in the vegetable samples differed between the two sampling site but were found to be within the permissible level set by FAO/WHO specifications and the vegetables can be used as sources of nutrients based on the proximate analysis obtained.
\end{abstract}

Keywords: Heavy Metals, Proximate, Pepper and Onion.

\section{INTRODUCTION}

Vegetables constitute an important part of the human diet since they are rich in carbohydrates, proteins as well as vitamins, minerals and trace elements. However; they contain both essential and toxic elements over a wide range of concentrations. Metals accumulation in vegetables may pose a direct threat to human health. Heavy metals are one of a range of important types of contaminants that can be found on the surface and in tissue of dry vegetables. Vegetables are also part of daily diets in many households forming an important source of vitamins and minerals required for human health. They are made up of chiefly cellulose, hemi-cellulose and pectin substances that support their texture [1].

Copyright @ 2020: This is an open-access article distributed under the terms of the Creative Commons Attribution license which permits unrestricted use, distribution, and reproduction in any medium for non commercial use (NonCommercial, or CC-BY-NC) provided the original author and source are credited. 
Vegetables absorbed metal from contaminated soils, while some deposited on different parts of the vegetables that are exposed to $t$ polluted environments. Vegetable plants growing on heavy metal contaminated medium can accumulate high concentrations of trace elements to cause serious health risk of consumers. Regular monitoring of heavy metals from effluents, sewage, in vegetables and in other food materials is essential for preventing excessive build-up of the metals in the food chain. Heavy metals depositions are associated with a wide range of sources such as small scale industries (including battery production, metal products and metal smelting industries etc); brick kilns; vehicular emissions; resuspended road dust and diesel generator. These were the important contributors to the contamination found mainly in vegetables. Heavy metals, such as cadmium, copper, lead and zinc are important environmental pollutants, particularly in areas under irrigated with waste water. Metals such as lead, zinc, copper and cadmium are common poisonous. These metals cause environmental hazards and are reported to be exceptionally toxic. Heavy metals may enter the human body through inhalation of dust, direct ingestion through consumption of food plants grown in metal contaminated soil, indicated that the cadmium concentrations in shoots and roots varied both with different cadmium levels and type of vegetable crop was increased with the increasing cadmium concentrations in the growth medium [1].

Onions (Allium cepa L.) are a natural part of the daily diet for most of the population and are a crop of great economic importance in all over the world [2]. It has been used as an ingredient in various dishes as cooked or raw for thousands of years by many cultures around the world. In Bangladesh, onion (red) is the most important crop among the spices and is an integral part of diet. Pepper, chili, or chili belongs to the Solanaceae family genus Capsicum and is closely related to tomato, eggplant, potato and tobacco. The genus Capsicum represents a diverse plant group and includes twenty-seven species; five domesticated and twenty-two un-domesticated [3]. Capsicum annuum, C. frutescens, Capsicum genus, Capsicum baccatum and Capsicum pubescens are considered domesticated species of peppers. Peppers are quite diverse and may be classified by the trade according to the end use. Peppers grown for their characteristics hot flavor are of genus Capsicum, Capsicum annuum principally and Capsicum frutescens to a lesser extent. Red Pepper is an important agricultural crop, not only because of its economic importance, but also due to nutritional and medicinal value. These are the excellent source of natural colors and antioxidant compounds [4]. A wide spectrum of antioxidant vitamins, carotenoids, and phenolic compounds are present in pepper. The intake of these compounds in food is an important health-protecting factor by prevention of widespread human diseases. As consumption continues to increase, red peppers could provide important amounts of nutritional antioxidants to the human diet [5]. This paper is aimed to compared the level of heavy metal and nutritional values in two commonly cultivated Capsicum annuum (Pepper) and Allium cepa L. (Onion) from two farming communities in Kazaure Local Government area.

\section{Matrials ANd Methods \\ Sampling of Vegetables and Soil \\ Vegetable Sampling}

The two species of vegetables Capsicum annuum (Pepper) and Allium cepa L. (Onion) was sampled from the two farming areas. The samples were collected from the farmlands during the second harvesting season 3 months after sowing. Three sampling plots of $9 \mathrm{~m}^{2}$ was demarcated within each farmland. Each plot served as replicate. Within each plot samples of six plants of each vegetable Capsicum annuum (Pepper) and Allium cepa L. (Onion) fruits was randomly collected or harvested and place in polythene bags and labelled according to their plant type, part and farmland. They were taken to the laboratory for preparation and analysis.

\section{Preparation of Vegetable for heavy metal analysis}

The collected samples were separated and clean first with tap water followed by with distilled water to eliminate suspended particles. The calyx and pedicel was removed from all fruit samples and added to their respective shoots. Samples was cut into smaller pieces with a plastic knife. The samples were put in different crucibles and ash in a furnace at $650^{\circ} \mathrm{C}$ for two hours. A quantity of the ash $(0.4 \mathrm{~g})$ from each plant sample was weighed separately into a beaker. To each, $3 \mathrm{ml}$ of concentrated $\mathrm{HCl}$ and $1 \mathrm{ml}$ of concentrated $\mathrm{HNO} 3$ were added, and heated on a hot plate at $100^{\circ} \mathrm{C}$ for 10 minutes to destroy any oxidizable materials and carbonates. The solutions were topped with deionized water to the $30 \mathrm{ml}$ mark and filtered using a Whatman filter paper. The filtrate was analyzed for the presence of heavy metals.

\section{Preparation of Vegetable for Proximate composition evaluation}

Pepper and Onion were collected freshly from the farm lands. The vegetables were washed with distilled water and thinly sliced, and then treated with chlorine concentrated solution. These samples were oven dried at temperature of $60^{\circ} \mathrm{C}$ for 24 hours. The samples were ground with a blender (Model No. 205) and stored in air-tight container. Each sample $(100 \mathrm{~g})$ was weighed and extracted with methanol which was used for the proximate composition.

\section{Atomic Absorption Spectrometer (AAS) Methods for the Determination of Heavy Metals}

Atomic Absorption Spectrometer (AAS) was used for the analytical determination of the heavy metals. The instrument uses light to measure the concentration of gas phase atoms. The atoms absorb light and make transitions to higher energy levels. Since each element has a unique electronic structure, the wavelength of light at which the 
absorption would take place is a unique property of each individual element. The source of light is a hallow cathode lamp made of the same element as the metal of interest. The metal concentration is determined from the amount of light absorbed. To determine the concentration of heavy metals of interest filtrates were aspirated into the excitation region of the AAS where they desolvated, vaporised and atomised by a flame discharge. The monochromator was used to isolate the specific wavelength of light emitted by the hallow cathode lamp from the non-analytical ones. The hallow cathode lamp used depended on the metal being analysed. A light sensitive detector measured the absorbed light and a computer measured the response of the detector and translated this into concentration.

\section{PROXIMATE COMPOSTION}

\section{Determination of Moisture Content}

The method described by A.O.A.C [6] was adopted; A clean crucible was dried to a constant weight in air oven at $110^{\circ} \mathrm{C}$, cooled in a desiccator and Weighed (W1). Two grams of finely ground sample was accurately weighed into the previously labeled crucible and reweighed (W2). The crucible containing the sample was dried in an oven to constant Weight (W3). The percentage moisture content was calculated thus:

$$
\% \text { Moisture content }=\frac{\mathrm{W} 2-\mathrm{W} 3}{\mathrm{~W} 2-\mathrm{W} 1} \times 100
$$

\section{Determination of ash content}

The A.O.A.C [6] method was used. The porcelain crucible was dried in an oven at $100^{\circ} \mathrm{C}$ for $10 \mathrm{~min}$, cooled in a desiccators and weighed (W1). Two grams of the finely ground sample was placed into a previously weighed porcelain crucible and reweighed (W2), it was first be ignited and then transferred into a furnace which was set at $550^{\circ} \mathrm{C}$. The sample was left in the furnace for eight hours to ensure proper ashing. The crucible containing the ash was then removed; cooled in a desiccator and Weighed (W3).

The percentage ash content was calculated as follows:

$$
\% \text { Ash Content }=\frac{\mathrm{W} 3-\mathrm{W} 1}{\mathrm{~W} 2-\mathrm{W} 1} \times 100
$$

\section{Determination of crude lipid content by soxhlet method}

A clean, dried $500 \mathrm{~cm}$ round bottom flask containing few anti-bumping granules were weighed (W1) with 300 c petroleum ether $\left(40-60^{\circ} \mathrm{C}\right)$ for extraction poured into the flask filled with soxhlet extraction unit. The extractor thimble weighing twenty grams was fixed into the Soxhlet unit. The round bottom flask and a condenser were connected to the Soxhlet extractor and cold water circulation was connected/put on. The heating mantle was switched on and the heating rate adjusted until the solvent refluxing at a steady rate. Extraction was carried out for 6hours. The solvent was recovered and the oil dried in an oven set at $70^{\circ} \mathrm{C}$ for 1 hour. The round bottom flask and oil was then Weighed (W2). The lipid content was calculated thus:

$$
\begin{gathered}
\% \text { Crude Lipid content }=\underline{\mathrm{W} 2-\mathrm{W} 1} \\
\text { Weight of Sample }
\end{gathered}
$$

\section{Determination of crude fibre}

The sample ( $2 \mathrm{~g}$ ) was weighed into a round bottom flask, $100 \mathrm{~cm} 0.25 \mathrm{M}$ sulphuric acid solution was added and the mixture boiled under reflux for $30 \mathrm{~min}$. The hot solution was quickly filtered under suction. The insoluble matter washed several times with hot water until it become acid free. It was quantitatively transferred into the flask and $100 \mathrm{~cm}$ of hot $0.31 \mathrm{M}$, Sodium Hydroxide solution was added, the mixture boiled under reflux for 30 min and filtered under suction. The residue washed with boiling water until it become base free, dried to constant weight in an oven at $100^{\circ} \mathrm{C}$, cooled in a desiccator and weighed $(\mathrm{C} 1)$. The weighed sample $(\mathrm{C} 1)$ was then incinerated in a muffle furnace at $550^{\circ} \mathrm{C}$ for 2hours, cooled in a desiccator and reweighed (C2).

Calculation: The loss in weight on incineration $=\mathrm{C} 1-\mathrm{C} 2$

$$
\% \text { Crude fibre }=\quad \underline{\mathrm{C} 1-\mathrm{C} 2} \times 100
$$

Weight of original sample

\section{Determination of nitrogen and crude protein}

The ground defatted sample $(91.5 \mathrm{~g})$ in an ashless filter study was dropped into a $300 \mathrm{~cm}$ Kjeldahl flask. The flask was then transferred to the Kjeldahl digestion apparatus. The sample was digested unit a clear green colour obtained. The digest was cooled and diluted with $100 \mathrm{~cm}$ with distilled water. Distillation of the digest: Into $500 \mathrm{~cm}$ Kjeldahl flask containing anti-bumping chips and $40 \mathrm{~cm}$ of $40 \% \mathrm{NaOH}$ were slowly added to the flask containing mixture of $50 \mathrm{~cm} 2 \%$ boric acid and 3 drops of mixed indicator was used to trap the ammonia being liberated. The 
conical flask and the Kjeldahl flask was then placed on Kjeldahl distillation apparatus with the tubes inserted into the conical flask, heat was applied to distill out the $\mathrm{NH}_{3}$ evolved with the distillate collected into the boric acid solution. The distillate was then titrated with $0.1 \mathrm{MHCl}$.

Calculation

$$
\% \mathrm{~N} 2=\frac{14 \times \mathrm{M} \times \mathrm{Vt} \times \mathrm{V}_{100}}{\text { Weight of sample }(\mathrm{mg}) \times \mathrm{Va}}
$$

$\%$ Crude Protein $=\%$ N2 $($ Nitrogen $) \times 6.35$

Where, $\mathrm{M}=$ Actual Molarity of Acid V = Titre Value (Volume) of $\mathrm{HCl}$ used V t = Total volume of diluted digest $\mathrm{Va}=$ Aliquot volume distilled

\section{Determination of carbohydrate by (difference)}

The total carbohydrate was determined by difference. The sum of the percentage moisture, ash, crude lipid, crude protein and crude fibre were subtracted from 100 [7].

Calculation:

$\%$ Total carbohydrate $=100-(\%$ moisture $+\%$ Ash $+\%$ fat $+\%$ Protein $+\%$ Fibre $)$

\section{Calorific value}

This was done by summing the multiplied values for crude protein, fats, and carbohydrate (exclude crude fibre) by the following factors $(4,9$ and 4$)$.

\section{Data Analysis}

Data obtained was subjected to Analysis of Variance (ANOVA) using SPSS version 16 with values for $\mathrm{p}<0.05$ considered significantly different.

\section{RESUlT AND DisCUSSION}

Heavy Metals Evaluation of Capsicum annuum (Pepper), Allium cepa L.(Onion) and their Respective Soil from Two Farming Communities in Kazaure Town

The concentration of lead $(\mathrm{Pb})$, cadmium $(\mathrm{Cd})$, manganese $(\mathrm{Mn}), \operatorname{zinc}(\mathrm{Zn}), \operatorname{copper}(\mathrm{Cu})$ and iron $(\mathrm{Fe})$ in Capsicum annuum (Pepper)and Allium cepa L.(Onion) sampled from the two farming community (Firji and Gada) was calculated from their corresponding absorbance value using the calibration curve. The heavy metal levels determined were based on plants dry weight, the mean level of $\mathrm{Pb}, \mathrm{Cd}$ and $\mathrm{Mn}$ were not detected from the pepper obtained from Gada farming community, while $\mathrm{Zn}, \mathrm{Cu}$ and $\mathrm{Fe}$ were found to be $1.5 \pm 0.10,0.74 \pm 0.02$ and $4.21 \pm 0.33 \mathrm{mg} / \mathrm{kg}$ respectively. Onion obtained from Gada area showed no any detectable level of $\mathrm{Pb}$, however, $\mathrm{Cd}, \mathrm{Mn}, \mathrm{Zn}, \mathrm{Cu}$ and $\mathrm{Fe}$ were found to be $0.002 \pm 0.001$, $0.11 \pm 0.001,1.8 \pm 0.20,0.91 \pm 0.03$ and $3.85 \pm 0.36 \mathrm{mg} / \mathrm{kg}$ respectively. The soil sample of this area showed that mean heavy metal level $\mathrm{Pb}, \mathrm{Cd}, \mathrm{Mn}, \mathrm{Zn}, \mathrm{Cu}$ and $\mathrm{Fe}$ were found to be $0.20 \pm 0.002,0.16 \pm 0.02,231.1 \pm 7.00,47.4 \pm 4.11,32.2 \pm 5.00$, $200 \pm 8.00 \mathrm{mg} / \mathrm{kg}$. All this values were within the WHO/FAO [8] permissible limit. The pepper and onion harvested at Firji farming community were found to content $\mathrm{Pb}$ from non-detectable level in pepper to $0.10 \pm 0.001 \mathrm{mg} / \mathrm{kg}$ in onion, $\mathrm{Cd}$ from non-detectable level in pepper to $0.001 \pm 0.00 \mathrm{mg} / \mathrm{kg}$ in onion, $\mathrm{Mn}$ from non-detectable in pepper to $0.12 \pm 0.003 \mathrm{mg} / \mathrm{kg}$ in onion. While the $\mathrm{Zn}, \mathrm{Cu}$ and $\mathrm{Fe}$ in both pepper and onion cultivated in Firji ranged from $1.2 \pm 0.03$ to1. $6 \pm 0.10,0.80 \pm 0.12$ to $0.97 \pm 0.04$ and $3.95 \pm 0.62$ to $4.41 \pm 0.31 \mathrm{mg} / \mathrm{kg}$ respectively. The value obtained in all the heavy metal in Firji farming community were found to be high than that of Gada farming area. However, all the values are within the permissible limit of WHO/FAO (Table-1) [8].

The concentration of $\mathrm{Zn}$ is probably because it is considered as essential micronutrients for plants growth and can easily be taken up by plants. The present of $\mathrm{Zn}$ in the vegetable may also be related to the use of $\mathrm{Zn}$ in fertilizers and metal-based pesticides. The concentration of zinc and copper were within WHO guideline value in all analyzed samples. All analyzed samples that were collected from the Firji and Gada were within the permissible level set by FAO/WHO [8] for consumption. Vegetables are important part of every human diet. Consumptions of toxic heavy metals in unsafe concentrations through vegetables may lead to accumulation of $\mathrm{Pb}$ and cadmium that may cause serious injury to kidney and liver [9] and could cause problem such as: Lead - brain damage, seizure, central nervous system disorders, both acute and chronic, gastrointestinal disturbances, and damage a child's central nervous system, and reproductive system. Cadmium - accumulates in kidneys, alter glomerulus filtration. It also causes diarrhoea, stomach pains and severe vomiting, bone fracture, reproductive failure and infertility in some cases, damage to the central nervous system, damage to the immune system, psychological disorders and possibly DNA damage. 
In comparing the result of this study with cited in literature, the concentrations of $\mathrm{Cu}$ in onion and pepper samples found in this study was not in agreement with the results of Mohamed et al., [2]. When the level of Zn in onion and pepper obtained in this study is compared with reported by Onianwa et al., [10]. It is much lower than with the values reported by Mohamed et al., [2], the level of lead in the analyzed samples (, onion and pepper) from this study is higher than those recorded by Onianwa et al., [10]. But it is comparable with the values of Radwan et al., [9]. This difference in the concentration of heavy metals may be related to variation due to application of fertilizer, metal-based pesticide, at time transportation and, emission of vehicles, atmospheric deposition and soil composition, While the different obtained between the two vegetables may be associated with the hill area of firji which has acid soils with small content of clay and mineral underground poor in heavy metals [11].

Table-1: Heavy metals evaluation of Capsicum annuum (Pepper) and Allium cepa L.(Onion) from two farming communities in Kazaure town

\begin{tabular}{|l|l|l|l|l|l|l|l|}
\hline Farm lands & \multicolumn{7}{|c|}{ Heavy Metal level $\mathbf{( m g / k g}$ ) } \\
\hline Gada Farming area & Vegetables & Pb & Cd & Mn & Zn & Cu & Fe \\
\cline { 2 - 8 } & Pepper & ND & ND & ND & $1.5 \pm 0.10^{\mathrm{h}}$ & $0.74 \pm 0.02^{\mathrm{k}}$ & $4.21 \pm 0.33^{\mathrm{n}}$ \\
\cline { 2 - 8 } & Onion & ND & $0.002 \pm 0.001^{\mathrm{c}}$ & $0.11 \pm 0.001^{\mathrm{e}}$ & $1.8 \pm 0.20^{\mathrm{h}}$ & $0.91 \pm 0.03^{\mathrm{k}}$ & $3.85 \pm 0.36^{\mathrm{o}}$ \\
\cline { 2 - 8 } & Soil & $0.20 \pm 0.002^{\mathrm{a}}$ & $0.16 \pm 0.02^{\mathrm{d}}$ & $231.1 \pm 7.00^{\mathrm{f}}$ & $47.4 \pm 4.11^{\mathrm{i}}$ & $32.2 \pm 5.00^{\mathrm{m}}$ & $200 \pm 8.00^{\mathrm{p}}$ \\
\hline \multirow{5}{*}{ Firji Faming area } & Vegetable & $\mathbf{P b}$ & $\mathbf{C d}$ & $\mathbf{M n}$ & $\mathbf{Z n}$ & $\mathbf{C u}$ & $\mathrm{Fe}$ \\
\cline { 2 - 8 } & Pepper & ND & ND & ND & $1.2 \pm 0.03^{\mathrm{h}}$ & $0.80 \pm 0.12^{\mathrm{k}}$ & $4.41 \pm 0.31^{\mathrm{q}}$ \\
\cline { 2 - 8 } & Onion & $0.10 \pm 0.001^{\mathrm{a}}$ & $0.001 \pm 0.00^{\mathrm{c}}$ & $0.12 \pm 0.003^{\mathrm{e}}$ & $1.6 \pm 0.10^{\mathrm{h}}$ & $0.97 \pm 0.04^{\mathrm{k}}$ & $3.95 \pm 0.62^{\mathrm{q}}$ \\
\cline { 2 - 8 } & Soil & $0.24 \pm 0.01^{\mathrm{b}}$ & $0.14 \pm 0.02^{\mathrm{d}}$ & $221.1 \pm 5.20^{\mathrm{g}}$ & $44.4 \pm 2.11^{\mathrm{j}}$ & $35.2 \pm 6.00^{\mathrm{m}}$ & $210 \pm 8.00^{\mathrm{p}}$ \\
\cline { 2 - 7 } & WHO/FOA & $0.30^{*}$ & $0.02^{*}$ & $500.00^{*}$ & $60^{*}$ & $40^{*}$ & $450^{*}$ \\
\hline
\end{tabular}

Result are presented in triplicate as mean \pm SD, Value with asterisk as superscripts are significantly (p $\geq 0.05)$ different along the column, values in same column with similar superscripts are significantly $(\mathrm{p} \leq 0.05)$ similar.

\section{Proximate Analysis of The Two Varieties Of Vegetables Capsicum Annuum(Pepper)And Allium Cepa L.(Onion) From Two Farming Communities In Kazaure Town (Gada And Firji Area}

The proximate analysis of the two varieties of vegetables Capsicum annuum(Pepper)and Allium cepa L.(Onion) from two farming communities in Kazaure town (Gada and Frji area). The onion showed high carbohydrate contents than that of pepper, however the carbohydrate of both pepper and onion were found to be high in Gada farming area than Firji farm the percent carbohydrate was ranged from (59.34 $\pm 0.01 \%$ to $64.00 \pm 5.00 \%)$. These high amounts of carbohydrates in both varieties signified its roles to human health, apart from the supply of energy, carbohydrates are also involving biochemical reactions not directly concerned with energy metabolism. Similarly, carbohydrates can serve as substrates for the production of aromatic amino acids and other phenolic compounds in Shikimate pathway and this may confer high phenolic and antioxidant potentials on both varieties. Thus the carbohydrate levels of the studied samples suggest its usefulness as alternative source of glucose.

The level of protein in Capsicum annuum (Pepper)and Allium cepa L.(Onion). were found to be low, however the protein content of the pepper and onion obtained from Gada ranged from $(11.70 \pm 0.13$ to $13.70 \pm 0.01 \%)$ the Gada one was higher than that of the Firji forming area which range from $(9.80 \pm 0.13$ to $11.60 \pm 0.01 \%)($ Table-2). The higher protein contents of onion in this studied, indicates that onion can contribute for hormones production which controls a variety of body functions such as growth, repair and maintenance of body tissues and organs. In addition, it may be useful as a preferred option to animal proteins for diabetics as the later tend to be high in saturated fats. This confirms that onion is a good source of energy.

Table-2: Proximate Compositions of the Two Varieties of Vegetables Capsicum Annuum(Pepper)And Allium Cepa L.(Onion) From Two Farming Communities in Kazaure Town Gada and Firji Area

\begin{tabular}{|l|l|l|l|l|l|l|l|}
\hline $\begin{array}{l}\text { Farm } \\
\text { lands }\end{array}$ & Vegetables & $\begin{array}{l}\text { Ash } \\
\text { contents } \\
(\boldsymbol{\%})\end{array}$ & $\begin{array}{l}\text { Moisture } \\
\text { content }(\boldsymbol{\%})\end{array}$ & $\begin{array}{l}\text { Carbohydrate } \\
(\boldsymbol{\%})\end{array}$ & $\begin{array}{l}\text { Fibre } \\
\text { content(\%)s }\end{array}$ & $\begin{array}{l}\text { Crude } \\
\text { contents }(\boldsymbol{\%})\end{array}$ & $\begin{array}{l}\text { Patein } \\
\text { contents }(\boldsymbol{\%})\end{array}$ \\
\hline $\begin{array}{l}\text { Gada } \\
\text { Farming } \\
\text { area }\end{array}$ & Pepper & $4.35 \pm 0.10^{\mathrm{a}}$ & $5.70 \pm 0.15^{\mathrm{e}}$ & $62.94 \pm 0.01^{\mathrm{h}}$ & $2.61 \pm 0.01^{\mathrm{j}}$ & $12.70 \pm 0.10^{\mathrm{n}}$ & $11.70 \pm 0.13^{\mathrm{r}}$ \\
\cline { 2 - 8 } $\begin{array}{l}\text { Firji } \\
\text { Faming } \\
\text { area }\end{array}$ & Onion & $6.10 \pm 0.20^{\mathrm{c}}$ & $9.30 \pm 1.00^{\mathrm{g}}$ & $64.00 \pm 5.00^{\mathrm{i}}$ & $4.47 \pm 1.00^{\mathrm{l}}$ & $14.60 \pm 2.10^{\mathrm{p}}$ & $13.70 \pm 0.01^{\mathrm{t}}$ \\
\cline { 2 - 8 } & Pepper & $3.34 \pm 0.10^{\mathrm{b}}$ & $3.90 \pm 0.15^{\mathrm{f}}$ & $59.34 \pm 0.01^{\mathrm{h}}$ & $1.91 \pm 0.01^{\mathrm{k}}$ & $10.40 \pm 0.10^{\mathrm{o}}$ & $9.80 \pm 0.13 \mathrm{~s}$ \\
\cline { 2 - 8 } & Onion & $5.20 \pm 0.20^{\mathrm{d}}$ & $8.20 \pm 1.00^{\mathrm{g}}$ & $59.61 \pm 5.00^{\mathrm{i}}$ & $3.89 \pm 1.00^{\mathrm{m}}$ & $11.50 \pm 2.10^{\mathrm{q}}$ & $11.60 \pm 0.01^{\mathrm{u}}$ \\
\hline
\end{tabular}

Values are mean \pm SD of 3 replicates. Test values along the same column carrying different superscripts for each parameter are significantly different $(\mathrm{p} \leq 0.05)$. 
Crude fiber is increasingly being understood as a useful tool for the control of oxidative processes in food products and as functional food ingredient. The presence of crude fiber in the diet is necessary for digestion and for elimination of wastes as well. The contraction of muscular walls of the digestive tract is stimulated by fiber, thus counteracting constipation [12]. In addition, it decreases the absorption of cholesterol from the gut in addition to delaying the digestion and conversion of starch to simple sugars, an important factor in the management of diabetes. It may reduce cerium cholesterol levels too. Crude fiber also functions in the protection against cardiovascular disease, colorectal cancer and obesity. Thus the high percentage fiber contents in onion and pepper were recorded from Gada form than obtained from Firji form (Table-2). However, the onion in all the farms revealed the higher contain of fibre than that of pepper, this make it useful in the management of diabetes mellitus and weight reduction in obsessed individuals. The high moisture content of both Capsicum annuum(Pepper)and Allium cepa L.(Onion) obtained from the two locations reveals that there is need for appropriate preservation as they will be prone to deterioration. It makes them susceptible to infection by micro-organisms. The high water content helps the body as the body does not need to use some of its own water to digest them. This means that the body uses less energy and resources to digest and can then assimilate all the nutrients much faster. Less pressure is therefore put on the digestive system [13].

The study of ash content is very important to the extent that it provides an insight into the nutritionally important inorganic mineral elements. It was reported that the ash content of a food sample gives an idea of the mineral elements present in the food sample [14]. In the present study, both the onion and pepper in all the two farms exhibited low level of ash content. Yet, could be promising sources of essential or non - essential mineral elements as it holds higher level of ash content $(6.10 \pm 0.20 \%)$ (Table-2). The crude fats showed that both onion and pepper were found to have low. The effect of excess intake of crude fat has some well-established health implications especially for the overweight. The consumption of excess amounts of fats has been recognized as the most important dietary factor aiding increased level of cholesterol. Besides the cholesterol implications due to high fat intake, obesity is a factor in the causation of disease [15]. Therefore, Capsicum annuum(Pepper)and Allium cepa L.(Onion) obtained from the two locations could be used to reduce the risk of coronary heart disease and lower the risk of hypertension due to its lower crude fat content of about $(10.40 \pm 0.10 \%$ to $12.70 \pm 0.10 \%)$.

\section{CONCLUSION}

In conclusion, the levels of metals in the vegetable samples differed between the two sampling site but were found to be within the permissible level set by FAO/WHO specifications in all vegetable samples collected. While the two vegetables analyzed based on their moisture content, ash content, crude lipid, crude fiber, crude protein and carbohydrate can be considered as good source of nutrients.

\section{ACKNOWLEDGEMENT}

The authors wish to acknowledged Tertiary Education Trust fund (TETFUND) Nigeria and Hussaini Adamu Federal Polytechnic Kazaure, Jigawa State. Nigeria for sponsoring the Research under Institutional Based Research Grant (TETFUND/DESS/POLY/KZR/2018).

Conflict of Interest: The authors declared no any conflict of interest.

\section{REFERENCES}

1. Sobukola, O. P., Dairo, O. U. (2007). Modeling drying kinetics of fever leaves (Ocimum viride) in a convective hot air dryer. Niger. Food Journal, 25(1):145-153

2. Farooq, M., Anwar, F., \& Rashid, U. (2008). Appraisal of heavy metal contents in different vegetables grown in the vicinity of an industrial area. Pakistan Journal of Botany, 40(5), 2099-2106.

3. Bosland, P. W. (1993). An effective plant field cage to increase the production of genetically pure chile (Capsicum spp.) seed. HortScience, 28(10), 1053-1053.

4. Howard, L. R., Talcott, S. T., Brenes, C. H., \& Villalon, B. (2000). Changes in phytochemical and antioxidant activity of selected pepper cultivars (Capsicum species) as influenced by maturity. Journal Agric. Food Chem, 48:1713-1720.

5. Lee, Y., Howard, L. R., \& Villalon, B. (1995). Flavonoids and antioxidant activity of fresh pepper (Capsicum annuum) cultivars. Journal Food Sci, 60:473-476.

6. AOAC. (2002). Official Methods of Analysis 17th edn, Washington DC. Association of Official Analytical Chemists.

7. Bahemuka, T. E., \& Mubofu, E. B. (1999) Heavy metals in edible green vegetables grown along the sites of the Sinza and Msimbazi rivers in Dares Salaam, Tanzania. Journal Food Chem, 66:63-66.

8. WHO / FAO. (2007). Expert committee on food additives. Cambridge: Cambridge University Press; $329-36$. 
9. Radwan, M. A., \& Salama, A. K. (2006). Market basket survey for some heavy metals in Egyptian fruits and vegetables. Food and Chem. Toxicol, 44:1273-1278.

10. Onianwa, P. C., Adeyemo A. O. Idowu, O. E., \& Ogabiela, E. E. (2001). Copper and zinc contents of Nigerian foods and estimates of the adult dietary intakes, Food Chem, 72:89-95.

11. Gergen I., Gogoasa I., Ursulescu, M., \& Man, E. (2000). Metal Elements in Environment, Medicine and Biology, Publishing House Eurobit, Timisoara, 4:151-154

12. Ponnusamy, S., \& Vellaichamy, T. (2012). Nutritional assessment, polyphenols evaluation and antioxidant activity of food resource plant Decalepis hamiltonii Wight \& Arn. Journal of Applied Pharmaceutical Science, 2(5):106110

13. Kwenin, W. K. J., Wolli, M., \& Dzomeku, B. M., (2011). Assessing the nutritional value of some African indigenous green leafy vegetables in Ghana. Journal of Animal \& Plant Sciences, 2(2):16-23.

14. Edeogu, C. O., Ezeonu, F. C., Okaka A. N. C., Ekuma, C. E., \& Elom, S. O. (2007). Proximate composition of staple food crops in Ebonyi State (South Eastern Nigeria). International Journal of Biotechnology and Biochemistry, 3(1):1-8

15. Wardlaw, G. M., \& Kessel, M. (2002). Prospective in Nutrition, $5^{\text {th }}$ ed., Boston: McGraw-Hill. 278. 